\begin{tabular}{l|l} 
The \\
Journal of \\
Social \\
Science
\end{tabular}

DOI Number: 10.30520/tjsosci.688610

\title{
FOREIGN POLICY PERSPECTIVES AND SUPERPOWER POLITICS: COMPETITION OF U.S. AND RUSSIA OVER KOSOVO
}

Efe SIVIŞ*

\begin{abstract}
Kosovo's proclamation of independence in 2008 led various reflections on U.S. and Russia. While the president George W. Bush looked with favor of Kosovo's declaration, Russia argued that it was a infringement of international law and of Serbia's territorial integrity. The 1999 NATO bombing of the Federal Republic of Yugoslavia, that to a certain extent gained Kosovo an additional impetus to break away from Serbia and Montenegro, is debated to this day since it was not supported by the United Nations Security Council. The policy of non-intervention and exempting local authorithy from foreign influences are two primary objectives of the Westphalian model - the main theoretical framework on which this article is built. Drawing on these two main objectives, the paper tackles with the issue of Kosovo's statehood from the perspective of both the U.S. and Russia. While Kosovo's statehood is the focal point, the Western Balkan region is put in the spotlight to serve as a stage for competing superpowers.
\end{abstract}

Keywords: Westphalia, Territorial Integrity, Kosovo, U.S Foreign Policy, Russian Foreign Policy

\section{Introduction}

Following the dissolution of Yugoslavia in the 1990s and the bloodshed that followed, the Western Balkan region once again came under international limelight. The 1999 NATO operation, "Merciful Angel", against the Yugoslavia, intented at forcing Yugoslav armed forces to withdraw from Kosovo. Following the withdrawal of the troops and under the surveillance of United Nations, United Nations Interim Administration in Kosovo (UNMIK) was established as per the Security Council Resolution 1244, suggesting, among other things, that Kosovo is to "enjoy substantial autonomy within the sovereign territory of Yugoslavia" (UNSC Resolution 1244). Serbia and Russia have insistently quoted Resolution 1244 and the Helsinki Final Act in favor of the sovereignty of Serbia over Kosovo (Randazzo 2010: 152). Under such an arrangement, Kosovo declared independence from Serbia in 2008, thereby causing a decade long bilateral dispute with Serbia. The conflict over Kosovo's legem is affecting both the policies of Serbia and Kosova on the issue of the Serbian people residing in Kosovo. Rather than collaborating to develop life standards and establish the law based system in Kosovo, both sides are seeking to increase their influences. Within this scope, the issue is controversial and complicated due to the fact that the past problems are not remained as a historical facts but they are still connected to daily politics (Hoogenboom, 2011: 7). What was regarded to be a bilateral issue between Serbia and Kosovo, suddenly turned into

\footnotetext{
* Asst. Prof., Fenerbahce University, Faculty of Economics and Administrative Sciences, Department of Political Science and International Relations, efe.sivis@ fbu.edu.tr
} 
an international conflict with serious implications for not only the region as a whole but also the relations between Russia and the U.S. and NATO, in this respect.

It was mainly at the U.S. initiative that NATO began carrying out an air strike against Serbia in 1999. Although not being of particular interest to the U.S. presidential administration prior to that, the volatility of the region and Kosovo's status within Serbia triggered the interest of the U.S. and the country is considered as an element of the U.S. foreign policy aspirations (Marleku et al, 2017: 41). To this day, the U.S. keeps supporting an independent Kosovo that is fully integrated into the international community. U.S. aids targets helping Kosovo to establish a consolidated democracy, which would also be compatible with Europe in economic terms. U.S. Department of State and USAID foreign assistance prioritize the full implementation of international agreements to normalize Kosovo-Serbia relations and works to establish transparent and responsive government institutions. Besides that, U.S. troops keeps participating in the Kosovo Force (KFOR) led by NATO to ensure a peaceful atmosphere for the people of Kosovo. The U.S. is the leading KFOR supporter among 27 nations that are backing it (U.S. Department of State, 2019).

Contrary to the U.S. foreign policy towards Kosovo's statehood, Russia condemns 1999 NATO actions in Kosovo. "The outbreak of war in Kosovo has sounded an alarm for us all. A regional military organization, in the name of humanitarianism and human rights, bypassed United Nations and took military action against a sovereign state. It created an ominous precedent in international relations." (Krieger, 2001: 459). Moreover, Moscow's policy of close relations and cooperation with Belgrade served the cause of the Russian leadership, hoping to strengthen its own position in the EU and global politics more broadly (Radeljic, 2017: 298). In August 2018, Maria Zakharova, Russian Foreign Ministry Spokeswoman, declared Russian position vis-à-vis Kosovo: "As for Kosovo, our position does not depend on the situation. It is clear and transparent and is based on several elements. First, it is the frame of international law: the United Nations Security Council resolution is still in effect, and those countries that are picturing themselves as the most ardent advocates of international law must keep in mind that resolution 1244 is on the table; second, it is respect to Serbia's sovereignty and to its domestic laws; third, it is understanding of the national interests of Serbia and its people" (Tass, 2018). In this respect, while the U.S. is backing and establishing dialogue between the Western Balkan countries and EU and NATO representatives, Russia is keeping to support the status quo, additionally complicating the situation and heighten the political tensions in the region.

This article, therefore, argues that the Kosovo crisis and the subsequent NATO bombing of Federal Republic of Yugoslavia split the super powers - the U.S. and Russia and, by doing so, set a precedent which has not only "haunted" the U.S. for years to come but has also caused a major deterioration in U.S.-Russia relations. With the 1999 bombing of the Federal Republic of Yugoslavia, U.S. - along with other NATO allies - undermined the international law by bypassing the UN Security Council and utilized an ad hoc Western coalition to grant secessionist entity independence. Those measures set a precedent regarding ethnic secessionist tendencies at the expense of the West as Russia utilized precisely Kosovo case to justify the Kremlin's support for the secession of Abkhazia and South Ossetia from Georgia in 2008 and the annexation of Crimea in 2014.

The first part sets the Kosovo issue within the broader geopolitical framework, considering the West with the U.S. at the forefront and Russia as the most influential actors. The second part introduces the theoretical framework, explaining the Westphalian sovereignty that foresees exemption from foreign influences in domestic politics. Moreover 
the concept of sovereignty in the light of Westphalia is strongly correlated with the notion of non-intervention, stressing that states have to value each other's rights to proceed in their internal political affairs. The third part of the article gives an overview of Kosovo's struggle for independence, starting from the collapse of Yugoslavia. This part also looks into the Western stance to the bombing, leading to Kosovo independence in 2008. The fourth part examines the Russian foreign policy on Kosovo issue and dwells on Moscow's aspirations to defend Serbian position for the sake of ensuring its own interests.

\section{The Concept of Westphalian Sovereignty}

Treaty of Westphalia that was signed in 1964, terminated the Thirty Years' War that took place in Central Europe between 1618 and 1648. Regarded as the first pan-European war in history, the war began in the fragmented Roman Empire among various Protestant and Catholic states, bringing in all European great powers gradually. Following long and comprehensive negotiations, among 16 European states and approximately half of the Imperial States, the peace talks restructured the norms of the modern governance and paved the way for the "Westphalian" system (Caporaso, 2000: 1). The Peace of Westphalia, thereby, made up of two treaties that are the Treaty of Münster and the Treaty of Osnabrück - which stipulated sovereignty over territories for a number of countries. Hershey

mentioned the Peace of Westphalia as a "sort of international constitution which remained the basis of its public law down to the French Revolution" (Hershey, 1912: 20). The model that was shaped with Westphalia, suggests that relations between people and local authorities would be exempted from foreign interference. The local authorities within particular borders may determine their connections free from any foreign factors (Krasner and Froats, 1999: 45). Stephen D. Krasner (1999) considers the Westphalian model of sovereignty as an institutional arrangement for organising political life that leans on two principles: territoriality and the exclusion of external actors from domestic authority structures. Westphalian sovereignty is infringed when foreign figures influence local administrations. The basic norm of Westphalian sovereignty is that states exist in specific territories, within which domestic political authorities are the sole arbiters of legitimate behaviour. According to various scholars, the nonintervention norm that is used to get infringed via dictates, coercive force, contrary to the self invitation is the central point of sovereignty concept (Krasner, 1999: 20).

Within this scope, the non-intervention concept was initially expressed by Wolff and Vattel in the end of 18th century. At the time, Wolff had written that interference in the internal affairs of other entities, is contrary to the essence of liberal rights of nations (Krasner, 1999: 21). Westphalia eliminated the remaining of hierarchical political system and established norms that aims at regulating connections among sovereign entities. Europe was transformed from hierarchy-based system that gains its legitimacy from God to a system that is based on anarchy where various actors with egual status interact with each other without a direct external pressure (Holsti, 2004: 5).

The initially established states in Europe following Westphalia had certain peculiarities. These states were not homogeneous, but they were consist of various entities such as fiefs, states, empires

The early modern European states system after Westphalia had various characteristics: it was politically heterogeneous, made up of many different types of polities, ranging from empires through states to free cities and numerous fiefs, some of them are 
armed, to pirates and private religious communities. The centralizing states were considerably weak and their territorial frontiers were ambiguous. Moreover these entities were not capable of implementing political or coercive force within its undetermined frontiers. The norms and regulations of trading activities or political connections, diplomacy were not set clear-cut, which led contradictions and conflicts (Holsti, 2004: 9-10).

With Congress of Vienna between 1814-1815 operating rules and principles of international systems established by Peace of Westphalia became basic norms of the international relations system. In this context, the fundamental actor of the international scene became the state with its defining features that are integrity, independence and sovereignty. The principle of equity among state actors was set as a norm, and the old claims for supremacy based on hierarchical orders that transcend state sovereignty were fully eliminated (Ţuţuianu, 2013: 46).

However, the international norms are based on Westphalia's outcomes, that determines the use of coercive force by the local and sovereign authority, started to shape international relations in late nineteenth century and early twentieth century, in contrast with the commonly believed argument that foresees Westphalia as the benchmark of national state formation (Al-Kassimi, 2015: 1). Having said that, the Westphalian model became largely criticized by scholars who intended to redefine the concept and offer their perspectives. The primary principles that form the Westphalian model that are non-intervention and territoriality have persistently been challenged. More powerful states got involved with interventionist tendencies, enforcing national administrations in relatively small states to follow policies that are determined by outsider actors. The notion of autonomy and sovereignty in Westphalian terms, started to be confuted and contrasted by other factors such as basic rights and freedoms, liberties of minority groups, economic freedom, and the establishing global stability (Krasner, 1999: 8).

Within the scope of IR theory, Benno Teschke came to the fore with one of such critics. Accordingly, it is not possible to theorize Westphalian system on great states competition shaped by real politik and international balance of power. Accordingly the key point is that international relations does not lean on armed conflicts over lands or territories but multisided conflict resolutions within a globalized economy. Andreas Osiander goes a step further by questioning the common traditional portrayal of the Peace of Westphalia as the origin of a modern nation state system. He claims that the most important transition to a more modern system was accomplished by the French revolution and industrial revolution, rather than with the Treaty of Westphalia. Osiander argues that nowhere in the treaties the word "sovereignty" itself is used. Those who intend to correlate the emergence of the concept of state sovereignty with the Westphalia act "against the backdrop of a past that is largely imaginary" (Osiander, 2001: 252).

In a similar manner, Luís Moita goes along the same lines and claims that the notion of sovereignty did not emerge with Westphalia; so it cannot be regarded as the national statehood's starting point (Moita, 2012: 19). From his perspective, the formation of nation state as we know it today, was accomplished in particular entities which break with ancient political system, particularly France and U.S. In addition to that industrial revolution had been an important factor that led to national state formation in the late $18^{\text {th }}$ and $19^{\text {th }}$ centuries. In other words, Moita shares Osiander's opinion and argues that the modern nation state stems from the French revolution and the emergence of industrial capitalism. 


\begin{tabular}{l} 
Year:4, Volume:4, Number:7 / 2020 \\
\hline $\begin{array}{l}\text { The } \\
\text { Socinal of } \\
\text { Science }\end{array}$
\end{tabular}

\section{Heading to a New System: Post-Westphalia}

The Cold War period paved the way for new interpretations of the Westphalian system. Countries were suffering hardships in applying the system of Westphalia despite the fact that these states are sovereign in modern sense and treated equally by international community. During the Cold War, the state actors started to conduct proxy war where they infringe the international law. The utilization of such newly emerged non-state actors in international relations undermined the accumulated norms and international law that suggests Westphalian type of direct state connections (Al-Kassimi, 2015: 12). After the dissolution of Soviet Union, the redistribution of power took place, according to which states are not only sacrificing sovereignty in a globalized system but also transferring sovereignty to other rising actors, such as international organisations.

Along these lines, Jessica T. Mathews also regards the Westphalian system in the post-Cold War period. Accordingly, the international system suggested by Westphalia is gradually dissappearing (Mathews, 1997: 50). Not all scholars, however, reach a consensus on the issue. For instance, as Dabova (2014) puts it, the Westphalian system is still backbone of the international relations which is affected by the globalization process (Dabova, 2014: 43).

In spite of scholars not being able to reach a consensus on a contemporary concept and on the successor of the Westphalian model, the international system has inevitably transformed not only since the establishment of the Treaty of Westphalia in 1648 but even more following the end of bipolar world system with the Soviet's collapse. In light of this, civil war in Kosovo and related to that NATO's use of coercive force towards Yugoslavia provides an example of powerful states breaking away from the Westphalian state model for as the state as such no longer has the capability to decide over the legitimate use of coercive force within its territory. The interference of NATO in internal conflicts of Yugoslavia paved the way for questioning the established international system that points the national state as the security provider of the people. However in this case, it was an external actor, NATO who attempted and accomplished to intervene a dispute in a recognized, sovereign state in Westphalian terms (Ghaleb, 2011: 79). The case of Kosovo yet shows that the Westphalian system of order had been undermined on a frequent basis throughout decades. The necessity, thereby, to analyse the existing system of international relations and move towards a new one which would encompass new reality should be discussed and consequently embraced.

\section{Kosovo's Steps towards Independency}

After the dissolution of Yugoslavia, five new "units" emerged, Croatia, Slovenia, Bosnia and Herzegovina, Macedonia and Yugoslavia (FRY), made up of three provinces of Serbia, Montenegro and Kosovo (Naidu, 1999:1). When Slobodan Milosevic announced about his "Great Serbia" projection meaning to dissolve Kosovo's autonomy in 1989, the Albanian representatives of Kosovo Assembly proclaimed the independency of Kosovo within the Yugoslav Federation. In the referenda conducted two years after gave a result in favour of such proclamation (Abazi, 2008: 1). Following the violent riots that broke out against the pro-Serbian authorities in Kosovo, in fear of Kosovo's secession, Belgrade took strict measures against the rebels. Kosovan Albanians had strong support from Albania, which at the early 1990s proposed Kosovo to join Albania. These tendencies for "Greater 
Albania" which to this very day cause political setbacks with Serbia, seemed to heighten the tensions even more in FRY. In 1992, with the establishment of KLA and the proclamation of the Republic of Kosovo, the Serbian government began to take actions against the protests by destroying thousands of villages and exiling even more people. It was then that the Kosovo crisis aroused the attention of the United States, NATO, OSCE and the wider international community.

On 25 October 1998, the American diplomat Richard Holbrooke arrived at Belgrade and conducted a ceasefire deal with Slobodan Milosevic, president of FRY, who agreed to start negotiations over Kosovo's independence and accepted 1,800 monitors of the Organisation for Security and Cooperation in Europe (OSCE) to investigate the killings (Naidu, 1999: 2). On 24 March 1999, NATO, an anti-Communist military alliance of Western Europe led by the United States, decided to bomb Yugoslavia when the Belgrade government did not accept the terms dictated by the NATO leaders (Naidu, 1999: 7). The official name of the operation was set as "Operation Allied Force", while the United States called it "Operation Noble Anvil". The 78 days operation with bombings in FRY was the first military action of NATO ever since its foundation (Wedgwood, 1999: 828).

NATO bombings of FRY are controversial as NATO did not receive the United Nations Security Council's support for using force against Serbia. As 31 March 1998 dated UNSC Resolution 1160, puts it "the failure to make constructive progress towards the peaceful resolution of the situation in Kosovo will lead to the consideration of additional measures" and called upon "all States and all international and regional organisations to act strictly in conformity with this resolution [...]" (United Nations Security Council 1998). NATO legitimized its actions by referring to NATO Treaty and the Article 4 which suggests that "the Parties will consult together whenever, in the opinion of any of them, the territorial integrity, political independence or security of any of the Parties is threatened", noting that NATO intervention was approved by all NATO members after consultations took place. The problem was that neither of the parties constituting FRY (Serbia, Kosovo or Montenegro) was a NATO member, neither did the United Nations, whose was primarily responsible for maintaining international peace and security, approved the bombing. Former NATO Secretary General, Javier Solana, claimed that because Yugoslavia refused the calls and neglected related UNSC Resolutions, 1160 and 1199, NATO had right to start a military operation to the region of Yugoslavia (Valki, 2001: 45).

The outcome of NATO operation is determined in the Kumanovo Treaty on $9^{\text {th }}$ of June: the Yugoslavian armed forces' withdrawal from Kosovo and the establishment of a NATO force in the region, known as KFOR (Kosovo Force) (Manolache \& Chiş, 2015: 1). Kumanovo Agreement ${ }^{1}$ conducted among NATO led KFOR, Yugoslavia and Serbia, thereby, terminated the Kosovo war. Only a day after, the UNSC adopted Resolution 1244 confirming formation of United Nations Interim Administration Mission in Kosovo (UNMIK) which aimed at, among other things, providing international civil and security presence for the sake of controlling the course of politics ultimately ending up with democratic elections as suggested in UNSC Resolution 1244. Although this Resolution did not explicitly refers to the independency of Kosovo, the Serbian authority over Kosovo was limited by an international actor. In other words, despite the fact that it did not manage to secede from Serbia in legal terms, Kosovo was separated in practice that would possibly lead to an official separation (Lehne, 2009: 1).

\footnotetext{
${ }^{1}$ For more information, please see https://www.nato.int/kosovo/docu/a990609a.htm
} 


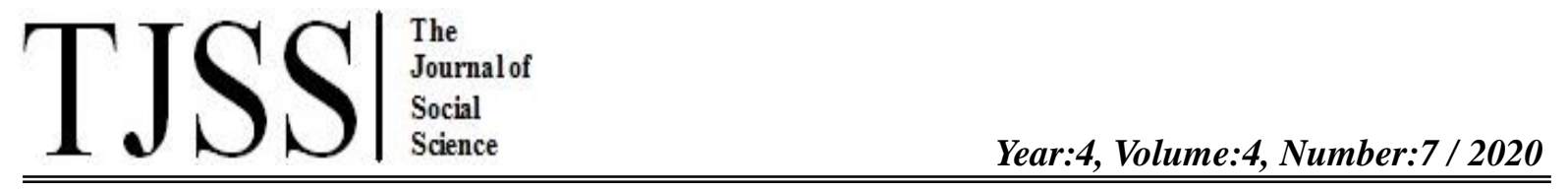

In 2005 a draft plan was prepared to determine the tomorrow of Kosovo. Marti Ahtisaari who was delegated as a special envoy to the United Nations Secretary General took charge of preparing the draft which consists of integrity of Kosovo with ongoing territorial boundaries (Caruso, 2008: 2-3). As such, the draft provided a basis for the formation of a sovereign Kosovo as legal entity with its own nation and security structures. Ultimately, on 17 February 2008, the independence of Kosovo's was proclaimed in Kosovan parliament that clearly pointed secession from Serbia.

\section{Western Stance to Kosovo's Declaration of Independence}

Kosovo's proclamation of independence was a turning point in the instable political atmosphere of the Balkans and led start of a different period regarding Kosovo issue. Kosovo, which was used to be a province of Yugoslavia and subjected to claims by Serbia, gained a true independency and proclaimed itself "a democratic, secular and multi-ethnic republic" (Tansey, 2009: 153). Kosovo's declaration was well received in the international community, with the majority of great powers recognizing its status.

The Kosovo government argues that their country has been recognized by 98 countries, in other words by majority of UN member states where except 5 of them (Cyprus, Slovakia, Romania, Spain, Greece) all European Union member states are included in the number. The refusing EU members have several reasons for their policies due to close relations with Serbia or reasons due to internal politics where they concern Kosovan case to be considered as an example for certain minority groups (Woehrel, 2013: 1). Although often compared to other secessionist incidents, the case of Kosovo is somewhat unique due to the interference of the international community. Kosovo had been ruled under an external actor which distinguishes the case from usual secessionist movements that are usually a matter of internal politics and legal zone. However UNSC Resolution 1244 carried the Kosovan case to the international arena and turned it into a matter of international politics (Borgen, 2008: 5).

Regarding the U.S. foreign policy on the issue, Washington declared that it recognizes Kosovo as a sovereign state by $18^{\text {th }}$ of February 2008. President Bush approached favourably to a demand of Kosovo to conduct formal diplomatic connections with United States and claimed that "the United States welcomes the commitments Kosovo made in its declaration of independence to implement the Ahtisaari Plan, to embrace multi-ethnicity as a fundamental principle of good governance, and to welcome a period of international supervision" (U.S. Department of State, 2008). Former Secretary of State, Condoleezza Rice, joined in congratulation the people of Kosovo and claimed that "in light of the conflicts of the 1990 s, independence is the only viable option to promote stability in the region" (Hamilton, 2008). After the U.S.' recognition of Kosovo, former Serbian Prime Minister Vojislav Kostunica was quick to recall Serbian ambassador from Washington. "We all know that this unilateral, illegal, violent and immoral proclamation of a false state on the territory of Serbia was possible only under the auspices of brutal force, of the U.S. and NATO," he stated. "The proof is the attempt to avoid the United Nations, and the disunity among European Union member states in spite of unbearable pressure by the U.S." (World News, 2008). Nonetheless, ahead of one year anniversary of Kosovo's independence, former U.S. president Barack Obama transmitted an official note of congratulations and stressed that "the U.S. will continue to support a multi-ethnic Kosovo, independent and democratic, in its efforts to become a deserving member of the family of states" (Balkan Insight, 2009). The narrative and the U.S.' backing for the democratic state of Kosovo has not changed under president 
Trump either. Amid Belgrade-Pristina talks ${ }^{2}$ on 18 December 2018, president Trump sent a letter to Kosovo's president Hasim in which the U.S. president reaffirmed Kosovo as a critical partner and reassured Kosovo of "the U.S. efforts to guarantee the peace and stability of all of Europe, adding that "the United States has invested heavily in the success of Kosovo as an independent, sovereign state. We want your country to continue to grow" (President of the Republic of Kosovo, 2018).

As for the European Union, Kosovon case provides a major challenge for conducting the EU foreign policy, mostly because five EU Member States resist to recognize Kosovo. France was the first EU member to recognize Kosovo, followed by the UK and Germany with the rest $20 \mathrm{EU}$ member states to do so in the following period. Despite the lacking of common position on the issue, Kosovo is under the enlargement agenda of the European Union, being the potential candidate along with Bosnia and Herzegovina. The EU operates with Kosovo under 1244 Resolution $^{3}$, being fully aware of the disputed status of Kosovo and recognizing the hardships around Belgrade-Pristina negotiations. The conflict of Kosovo is, thereby, a political matter rather than a matter of law. The EU members who refuse to recognize have capability to block Kosovo's intend to take a step toward European Union considering internal political worries. On the other hand Kosovo's becoming a EU member seems not easy in near future due to the fact that none of the EU member has placed such move as top agenda (Dessus, Rexha, Merja, Stratulat, 2017: 1). However the EU keeps its presence in the region with Special Representative (EUSR), and the European Security and Defence Policy (ESDP) mission in the rule of law area (EULEX). Besides that it is active considering member states' Embassies and Liaison offices. The EU Office in Kosovo acts as a key figure for applying the EU agenda, particularly the encouraging European norms (European Union Office in Kosovo).

\section{Russian Foreign Policy on Kosovo}

Being a long time ally of Serbia and genuinely interested in the geopolitics of the Western Balkan region, Russia has regarded the problem of Kosovo's statehood as its own. Russia's stance on Kosovo aligns with its broader interests in the region, such as maintaining political and economic influence in the Balkans, as well as by attempting to block the integration of the Western Balkan states to the EU and NATO. With a solid emotional connection between Russia and Serbia, Russia has developed an attitude of a protégé of the 'little brother' (Kallaba, 2017: 6). It is apparent that Russia is not capable of conducting trade activity, make investment or give financial assistance as the EU does. However Kremlin managed to enhance its affect by instruments such as energy, finance and intelligence-armed forces to a certain limit. Moreover, it is crucial for Belgrade, that Russia gave backing to Serbia to follow a rigid foreign policy on Kosovo. This political backing was responsed positively in favour of Russia where Belgrade turned down to cooperate with EU in enacting sanctions against Russia as a response to Kremlin's interference in Ukraine (DirectorateGeneral for External Policies, 2017: 6).

Ever since the 1999 bombing of Yugoslavia, Russia has been a strong supporter of Serbia and a harsh critic of NATO. Russia approached NATO operation in Yugoslavia

\footnotetext{
${ }^{2}$ For more information, please see https://eeas.europa.eu/diplomatic-network/eu-facilitated-dialogue-belgrade-pristinarelations/349/dialogue-between-belgrade-and-pristina en

${ }^{3}$ This designation is without prejudice to positions on status, and is in line with UNSCR 1244/1999 and the ICJ Opinion on the Kosovo declaration of independence.
} 
negatively where the country's political elites besides other parts of society, calling the operation as "'barbaric,' 'genocidal' and 'Hitlerite" (Tuminez, 2000: 280). One of the reasons for Serbian rigid foreign policy stance on Kosovo, i.e. Belgrade's resisting to recognize and negotiate Kosovo's statehood, notably stems from Kremlin's resolute support. Kremlin's reaction to UN 1244 resolution which established UNMIK had been largely adverse. Russian foreign minister, Sergey Lavrov claimed that "the establishment of an independent state in Kosovo is fraught with serious implications for stability of Europe", noting that in case of enacting a UN decision that is contrary to Serbia, it would start questioning the existing UN resolution 1244. This would mean that Russia would critically approach how the Resolution guarantees Serbian territorial integrity. Moreover, it also claimed that Russia would seek whether thousand-person Serb armed forces are posted in Kosovo or not (Rettman, 2007).

Starting from 2008, Kosovo became one of the top agendas in Serbian foreign policy, an opportunity Russia capitalized on quite successfully. Moscow has lobbied against recognizing Kosovo as a sovereign state in the international community and used veto power for any possibility of Kosovo being admitted to the United Nations. Mainly because of Russia's harsh opposition to the independence of Kosovo, the membership to the UN currently seems not possible in near future (Rrecaj, 2008: 22). Moscow's policy of warm relations and cooperation with Belgrade not only led the cause of the Serbian representatives before the international community but also the cause of the Russian administration, aiming at consolidating its own position before European Union and globally (Radeljic 2017: 298). By having a veto vote in the United Nations Security Council, refusing to recognize Kosovo as a sovereign state and opposing country's admittance to the United Nations, Kremlin guaranteed its country's presence not only in the European Union politics but also on the international arena.

Moreover, maintaining the status quo on Kosovo also goes in Russia's favour as it prevents Serbia from moving towards an EU membership and joining the "Western Alliance". During his visit to Belgrade on 17 January 2019, President Putin claimed that "a serious factor of destabilisation is the policy of the U.S. and some Western countries which is aimed at strengthening their domination in the region", noting NATO's strikes against Yugoslavia in 1999, Kosovo's secession from Serbia and the "illegitimate recognition" of Kosovo's independence, "dragging Montenegro into NATO", and forcing Macedonia's accession to NATO and a change of its name contrary to the will of its citizens (HINA, 2019). The case of Kosovo, therefore, serves Russia's traditional interests that go beyond long term friendship with Serbia and implicate broader geopolitical framework under which Russia operates not only in the Western Balkan region but also in its post-Soviet region.

In light of this, while Russia has been insisting on territorial integrity when it comes to Kosovo, it entirely ignored it in the case of Ukraine. In order to legimitize this contradictory stance, in his interview with Bloomberg in September 2016, Putin claimed the following: "When they (West) remember Crimea, they try not to notice the will of people living in Crimea - where 70 per cent of them are ethnic Russians and the rest speak Russian as if it's their native language - was to join Russia. In one place, Kosovo, you can use the will of people, but not here". What came to be problematic for Belgrade was the comparison with Crimea when in 2008 following the Russian-Georgian war Kremlin recognized Abkhazia and South Ossetia as independent, referring to Kosovo as a precedent. When confronted with blaming of behaving contradictory in its implementation of international law, Kremlin argued that the cases of Kosovo and Abkhazia and South Ossetia are not equal due to the fact that Serbia had not attacked Kosovo however Georgia attacked South Ossetia, and 
thereby the happenings in South Ossetia should be considered as sui generis, and it was not similar to the experiences in Kosovo (Petrovic, 2010: 29). Equalizing the case of Crimea with that of Kosovo was regarded by Serbian public as a clear indication of Russian objective which explicitly favours Crimea over Kosovo, and in order to advocate its interests in the international community, Moscow is ready to renounce Kosovo. This contradictory stance could mean that the country which recognized Kosovo should also approve the annexation of Crimea as a legal act. Secondly, due to a political alliance between Russia and Serbia, Kremlin may not recognize Kosovo's statehood but might not prevent the country from becoming a United Nations member, which would conflict with Serbian foreign policy objectives.

\section{Conclusion}

Dated back to 17th century, the Westphalian outcomes formed a dynamic and adjustable system that was able to include new actors and confront varying hardships, such as the formation of international or supranational organizations (Dabova, 2014: 52). The Western consensus to recognize Kosovo's statehood and remove both Kosovo and Metohija from Serbia is perceived as a "threat" to the Westphalian order for as the current system of international law does not permit the secession to ethnic minorities; it only allows cultural rights, because ethnoreligious minority cannot be correlated with a nation (Ţuţuianu, 2013: 73). Kosovo campaign pushed the limits of international law by NATO's taking action and start a military operation regardless of any UNSC Resolution on the issue, causing serious debates on legal perspective of applying coercive force. Besides the operation also paved the way for questioning the UN as the key actor in maintaining international security and peace (Wippman, 2001: 129).

Tensions between newly formed Kosovo Liberation Army (KLA) and the army of State of Union of Serbia and Montenegro, of which Kosovo was part, consequently paved the way for the first NATO military operation in the Western Balkans. The 1999 NATO bombing of Federal Republic of Yugoslavia (utilized with the aim of preventing the outbreak of war and of ensuring rights of individuals) is an important example of post-Westphalian reasoning, as well as the fact that the external actors determine about Kosovo's domestic affairs. For example, 1) A 400-member U.N. mission in Kosovo (UNMIK) keeps to be deployed to Kosovo, 2) The European Union's rule-of-law mission (EULEX) has functioned in Kosovo under the EU's Common Security and Defense Policy (CSDP) since 2008, 3) International prosecutors and judges still guarantee equity in Kosovo's courts and the potential prosecution of Kosovo citizens, and 4) KFOR, a NATO-led peacekeeping force in Kosovo, has the role of guaranteeing Kosovo's overall security (Morelli, 2018: 2). During the Kosovo war, the United States quite literally led the military operation, whereas the European allies played a more moderate and low-profile role. Although NATO policy shaped the war and was determined in the North Atlantic Council, among no less than 19 member states, almost all of the intelligence information upon which decisions were made (i.e., where, when, and what to bomb) was provided by American sources (Van Ham, 2000: 7-8). Once Kosovo proclaimed its independence in 2008, the U.S. President Bush recognized country's statehood in the following day and committed the U.S. support in nation-building and consolidating democratic institutions.

On the other hand, for Russia, Kosovo's unilateral proclamation of independence was an evident infringement of the international law and of Serbia's territorial integrity. Although 
in 2010 International Court of Justice ruled in favour of Kosovo's independence, claiming that it was legal, neither Serbia nor Russia gives consent to such decision. As this article stresses, the reasons for Russian disapproving stance towards Kosovo lies not only in the long-time friendship with Serbia but also in its own traditional interests on the broader geopolitical scene. Moscow's foreign policy on territorial sovereignty is controversial since, on the one hand, Russia unequivocally resists to recognize Kosovo as a sovereign state, whereas, in the case of Abkhazia and South Ossetia, Russia recognizes the autonomy of both entities. Kosovo's controversial status goes in Russia's favour, mainly because Kremlin utilizes the case of Kosovo to legitimize its own foreign policy aspirations. This was the case with Crimea in 2014, where, unlike in the case of Kosovo, President Putin stressed the territorial integrity and pointed to the decision of the people in the Crimean referendum. This dual stance regarding international law does not suit the U.S. either for as the 1999 bombing of the Federal Republic of Yugoslavia did not have the support of the United Nations Security Council. The conflicting policies between NATO and Russia on Kosovo have broader geopolitical implications since NATO's decision to start a military operation despite opposition from Kremlin and without an explicit UN mandate, prompted Russian concerns about potential intervention in other regions, including areas of crucial interest to Kremlin such as post-Soviet region (Antonenko, 2007: 10).

To conclude, given that Serbia leans heavily on Russia with regards to the international recognition and admission of Kosovo to the United Nations, Kremlin remains in a more advantaged position when compared to U.S. Kremlin will, thereby, keep to be the only barrier in the way of Western attempts to create independent Kosovo as long as Russia has veto power in the UN Security Council to prevent any UN decision on the status of Kosovo that does not go in favour of both Belgrade and Pristina. The advocacy and foreign policies followed by the U.S. and Russia will prove crucial in facilitating or distorting SerbiaKosovo talks in near future. The only question is whether Kosovo will still be part of the Russian foreign policy agenda or, given Kremlin's contradictory stance on the territorial integrity, the focus will be shifted towards an entirely different geopolitical aspiration. 


\begin{tabular}{l} 
Year:4, Volume:4, Number:7 / 2020 \\
\hline $\begin{array}{l}\text { The } \\
\text { Social } \\
\text { Science }\end{array}$
\end{tabular}

\section{REFERENCES}

Abazi, E. (2008). Kosovo Independence: An Albanian Perspective. Policy Brief, No:11, Istanbul: Foundation for Political, Economic and Social Research.

Al-Kassimi K. (2015) The Obsolescence of the Westphalian Model and the Return to A Maximum State of Exception. Constanta: Journal of Political Science \& Public Affairs, S2: 007. doi:10.4172/2332-0761.S2-007

Antonenko, O. (2007). Russia and the Deadlock over Kosovo. Paris: Russia/NIS Center No:21.

Balkan Insight (2009). Obama Congratulates Kosovo on Independence. http://www.balkaninsight.com/en/article/obama-congratulates-kosovo-on-independence (Erişim Tarihi: 16.01.2019).

Borgen, C. J. (2008). Kosovo's Declaration of Independence: Self-Determination, Secession and Recognition. American Society of International Law. Washington: ASIL Insights.

Caporaso, J. A. (2000). Changes in the Westphalian Order: Territory, Public Authority, and Sovereignty. International Studies Review, 2 (2), 1-28.

Caruso, U. (2008). Kosovo declaration of Independence and the International Community an assessment by the Kosovo Monitoring Task Force. Journal on Ethnopolitics and Minority Issues in Europe, 7 (2), 1-33.

Dabova, E. L. (2014). The Westphalian Principles: Dead of Transformed and Adapted to New Reality?. International Journal of Humanities and Social Science Invention, 3 (4), 4354.

Dessus, Z., Rexha, A., Merja A., Stratulat C. (2017). Kosovo's EU Candidate Status: a Goal Within Reach? http://www.epc.eu/documents/uploads/pub_7812_kosovoseucandidatestatus.pdf $\quad$ (Erişim Tarihi: 21.01.2019).

Directorate General for External Policies (2017). Serbia's Cooperation with China, the European Union, Russia and the United States of America. http://www.europarl.europa.eu/RegData/etudes/STUD/2017/603854/EXPO_STU(2017)6038 54_EN.pdf (Erişim Tarihi: 16.01.2019).

European Union Office in Kosovo (2016). Kosovo and the EU. https://eeas.europa.eu/delegations/kosovo/1387/kosovo-and-eu_en. (Erişim Tarihi: 15.01.2019).

Ghaleb, A. (2011). End of Westphalia: The Implications of UN Resolution 1973 (2011) for the State-Territorial Sovereignty of Romania. Sfera Politicii, 4 (158), 75-82.

Hamilton, D. (2008). U.S. and EU Powers Recognize Kosovo as Some Opposed. https://www.reuters.com/article/us-kosovo-serbia/u-s-and-eu-powers-recognize-kosovo-assome-opposed-idUSHAM53437920080218 (Erişim Tarihi: 14.01.2019).

Hershey, S. A. (1912). History of International Law Since the Peace of Westphalia. The American Journal of International Law, 6 (1), 30-69. 
HINA (2019). Putin: Relations Between Russia and Croatia Progressing. https://www.totalcroatia-news.com/politics/33598-putin (Erişim Tarihi: 15.01.2019).

Holsti, K. J. (2004). From States Systems to a Society of States: The Evolution of International Relations. Jarrod Wiener \& Robert A. Schrire (Der), International Relations Vol. 1 içinde, (ss. 75-99). Paris: EOLSS.

Hoogenboom, J. (2011). The EU as a Peacebuilder in Kosovo. Brussels: Civil Society Dialogue Network (CSDN). http://eplo.org/wp-content/uploads/2017/02/CSDN_MSMeeting_Romania_Policy_Analysis_EU_as_a_Peacebuilder_in_Kosovo.pdf (Erişim Tarihi: 10.01.2019).

Jusufi, E. (2015). The Kosovo Precedent in the Secession and Recognition of Crimea, Iliria International Review. 5(1), 267-286.

Kallaba, P. (2017). Russian Interference in Kosovo: How and Why?. Prishtine: Kosovar Centre for Security Studies.

Krasner, S. D. (1999). Sovereignty: Organised Hypocrisy. Princeton, New Jersey: Princeton University Press.

Krasner, S. D. and D. Froats (1999). The Westphalian Model and Minority Rights Guarantees in Europe. https://core.ac.uk/download/pdf/71726469.pdf, (Erişim Tarihi: 17.01.2019).

Krieger, H. (2001). The Kosovo Conflict and International Law: An Analytical Documentation 1974-1999. New York: Cambridge University Press.

Lehne, S. (2009). Resolving Kosovo's Status.

http://www.oiip.ac.at/fileadmin/Unterlagen/Dateien/Arbeitspapiere/Policy_Paper_Status_of Kosovo.pdf, (Erişim Tarihi: 07.01.2019).

Manolache, D. and Chiş, C. (2015). NATO Bombing in the Former Yugoslav Republic of Yugoslavia. http://www.afahc.ro/ro/afases/2015/afases_2015/air_force/Manolache_Chis.pdf (Erişim Tarihi: 14.01.2019).

Marleku, A., Gashi, B., Krasniqi, V. (2017). The Role of US in the Security of Kosovo. http://cis01.central.ucv.ro/revistadestiintepolitice/files/numarul54_2017/4.pdf (Erişim Tarihi: 19.01.2019).

Mathews T, J. (1997). Power Shift. Foreign Affairs, 76, 50-66.

Moita, L. (2012). A Critical Review on the Consensus Around the "Westphalian system". Journal of International Relations, 3 (2), 17-42.

Morelli, V. L. (2018). Kosovo: Background and U.S. Relations. https://fas.org/sgp/crs/row/R44979.pdf, (Erişim Tarihi: 15.01.2019).

Naidu, M. V. (1999). NATO's War on Yugoslavia: Issues, Actors and Prospects. Peace Research, 31 (2), 1-23.

Osiander, A. (2001). Sovereignty, International Relations, and the Westphalian Myth. International Organization, 55 (2), 251-287.

Petrovic, Z (2010). Russian-Serbian Strategic Partnership: Scope and Content, in Russia Serbia Relations at the Beginning of XXI Century. http://www.isacfund.org/download/Russia-Serbia-Relations-at-the-beginning-of-XXI-Century.pdf (Erişim Tarihi: 04.01.2019). 
President of the Republic of Kosovo, Hasim Thaçi (2018). President Thaci received a letter from a President of the USA, Donald Trump.https://www.presidentksgov.net/en/news/president-thaci-received-a-letter-from-the-president-of-the-usa-donaldtrump (Erişim Tarihi: 17.01.2019).

Radeljic, B. (2017). Russia's involvement in the Kosovo Case: Defending Serbian Interests or Securing Its Own Influence in Europe?. Regional Studies of Russia, Eastern Europe, and Central Asia, 6(2), 273-300.

Randazzo, Elisa E. (2010). Kosovo: Independence or Empty Sovereignty?. The Western Balkans Policy Review, 1 (1), 146-167.

Rettman, A.(2007). Serbia and Russia React Differently to Kosovo Independence Plan. https://euobserver.com/foreign/23791 (Erişim Tarihi: 05.01.2019).

Rrecaj, B. (2008). Kosovo after the Declaration of Independence: Admission to UN, EU AND NATO. Croatian International Relations Review, 14 (50-51), 19-24.

Tansey, O. (2009). Kosovo: Independence and Tutelage. Journal of Democracy, 20 (2), 153 166.

TASS, Russian News Agency (2018). Russia's Position on Kosovo Remains Unchanged, Says Russian Diplomat. http://tass.com/politics/1017064 (Erişim Tarihi: 21.01.2019).

Teschke, B. (2002). Theorizing the Westphalian System of States: International Relations from Absolutism to Capitalism. European Journal of International Relations. 8(1), 5-48.

Tuminez, A. S. (2000). Russian Nationalism since 1856: Ideology and the Making of Foreign Policy. Maryland: Rowman \& Littlefield.

Țuţuianu, S. (2013). Towards Global Justice: Sovereignty in an Independent World, the Hague: Asser Press.

UNSC, United Nations Resolution 1244, https://unmik.unmissions.org/united-nationsresolution-1244 (Erişim Tarihi: 03.01.2019).

United Nations Security Council (1998), Resolution 1160 (1998), S/RES/1160, 31 March 1998 http://unscr.com/en/resolutions/doc/1160 (Erişim Tarihi: 11.01.2019).

U.S. Department of State (2019). U.S. Relations with Kosovo. Bureau of European and Eurasian Affairs, Fact Sheet. https://www.state.gov/r/pa/ei/bgn/100931.htm (Erişim Tarihi: 21.01.2019).

U.S. Department of State (2008). U.S. Recognizes Kosovo as an Independent State. https://2001-2009.state.gov/secretary/rm/2008/02/100973.htm (Erişim Tarihi: 13.01.2019).

Valki, L. (2001). Kosovo, International Law and Humanitarian Intervention. Institute of International Relations. Journal Perspectives. 15 (Winter), 45-67.

Van Ham, P. (2000). Europe's New Defense Ambition: Implications for NATO, the US, and Russia. https://www.bits.de/EURA/ham.pdf. (Erişim Tarihi: 09.01.2019).

Wedgwood, R. (1999). NATO's campaign in Yugoslavia. The American Journal of International Law. 93 (4), 828-834.

Wippman, D. (2001). Kosovo and the Limits of International Law. Fordham International Law Journal, 25 (1), 129-150. 
Woehrel, S. (2013). Kosovo: Current Issues and U.S. Policy. https://fas.org/sgp/crs/row/RS21721.pdf (Erişim Tarihi: 15.01.2019).

World News (2008). Serbia Recalls Ambassador After U.S. Recognizes Kosovo. https://www.reuters.com/article/us-kosovo-serbia-envoy/serbia-recalls-ambassador-after-u-srecognizes-kosovo-idUSL1888220320080218 (Erişim Tarihi: 11.01.2019). 